27. West, C. D., and Smith, W. C.: An attempt to elucidate the cause of growth retardation in renal disease. Amer. J. Dis. Child., 91: 460 (1956).

28. Widdowson, E. M.: Biology of gestation. In: N. S. Assali: The Fetus and Neonate, Vol II (Academic Press, New York, 1968).

29. Widdowson, E. M., and Spray, C. M.: Chemical development in utero. Arch. Dis Childhood, 26: 205 (1951).

30. Mead Johnson Laboratories, Toronto, Ontario, Canada.

31. Air-Shields (Canada) Ltd., Downsview, Ontario, Canada.

32. The authors wish to thank Dr. B. J. Reilly, Chief of Radiology, The Hospital for Sick Children, for the interpretation of radiographs; Mrs. B. Woode, R.N., for her assistance in caring for the babies; Mrs. D. Hanimyan, B. Sc., Mr. J. Fabenyi, B. Agr, and Mr. M. Kahn for their expert technical assistance. The authors are grateful to the Medical and Nursing Staff of the Neonatal Unit of the Hospital for Sick Children for their help and cooperation.

33. This research was supported in part by the Medical Research Council, Canada, Grant MA 4635.

34. Requests for reprints should be addressed to: I. C. Radde, M.D., Research Institute, The Hospital for Sick Children, 555 University Ave., Toronto 2, Ontario (Canada).

35. Accepted for publication July 31, 1974.

\title{
Growth and Mineral Metabolism in Very Low Birth Weight Infants. II. Effects of Calcium Supplementation on Growth and Divalent Cations
}

\author{
G. M. DAY, G. W. CHANCE, I. C. RADDE, (49) B. J. REILLY, E. PARK, AND J. SHEEPERS \\ Research Institute, The Hospital for Sick Children, Divisions of Neonatology and Endocrinology; Department of \\ Paediatrics, University of Toronto, Toronto, Canada
}

\section{Extract}

Infants of two groups, one of 16 , one of 14 infants, who weighed $<1.3 \mathrm{~kg}$ at birth (mean $1.01 \pm 0.05 \mathrm{~kg}$ ), were studied from age 14 days until they reached $1.8 \mathrm{~kg}$ body weight. Infants were pairmatched for gestational age and birth weight and one member was randomly allocated to two treatment groups. Infants in group $A$ received no calcium supplement and those in group $B$ received calcium lactate, $800 \mathrm{mg} / \mathrm{kg} / 24 \mathrm{hr}$, in divided doses with each feed. All were fed "Improved" SMA, $200 \mathrm{ml} / \mathrm{kg} / 24 \mathrm{hr}, 160 \mathrm{cal} / \mathrm{kg} / 24 \mathrm{hr}$, and were given a multivitamin preparation containing 500 IU vitamin $\mathrm{D}_{2} /$ dose.

The infants' weekly length gain did not differ between groups $(1.08 \pm 0.04 \mathrm{~cm} /$ week $v s 1.11 \pm 0.04 \mathrm{~cm} /$ week; mean \pm SEM $)$. Mean weight and head cercumference increments also were similar (group $A, 163 \pm 6 \mathrm{~g} /$ week; $1.12 \pm 0.03 \mathrm{~cm} /$ week; group $B, 170 \pm$ $6 \mathrm{~g} /$ week and $1.18 \pm 0.03 \mathrm{~cm} /$ week $)$.

An increase in blood $\mathrm{pH}$ from $7.33 \pm 0.01$ to $7.41 \pm 0.01(P<$ 0.01 ) in group $A$ babies was associated with a decrease in $\mathrm{PCO}_{2}$ from $44.2 \pm 1.0$ to $38.9 \pm 1.4 \mathrm{~mm} \mathrm{Hg}$. Values remained unchanged with age in group $B$ babies. After institution of calcium supplementation, base excess values differed transiently between groups (at age 5 weeks, group $A-\mathbf{0 . 1 6} \pm \mathbf{0 . 5 6} \mathbf{~ m E q} /$ liter, group $B$ $-2.23 \pm 0.76 \mathrm{mEq} /$ liter $; P<\mathbf{0 . 0 5}$ ).

Mean ionic calcium values remained unchanged in group $A(2.37$ $\pm 0.06 \mathrm{mEq} /$ liter), but increased slightly from $2.42 \pm 0.06$ to 2.57 $\pm 0.04 \mathbf{m E q} /$ liter in group $B(P<\mathbf{0 . 0 5})$. Total plasma calcium differed transiently between groups after calcium supplementation had started in group $B$ (Group $A, \mathbf{4 . 5 3} \pm \mathbf{0 . 0 8} \mathbf{~ m E q} /$ liter; group $B$, $4.82 \pm 0.12 \mathrm{mEq} / \mathrm{liter} ; P<0.05)$, and plasma $\mathrm{Mg}$ and $\mathrm{P}$ levels were lower in group $B$ babies than in group $A$ babies $(P<0.01)$. All infants remained somewhat hypoproteinemic throughout the study; mean values of plasma total protein averaged $4.5 \mathrm{~g} / 100 \mathrm{ml}$.
Mean urinary excretion rates of calcium initially were 0.17 $\mathrm{mEq} / \mathrm{kg} / 24 \mathrm{hr}$ in group $A$ babies and $0.18 \mathrm{mEq} / \mathrm{kg} / 24 \mathrm{hr}$ in group $B$ infants, and no increase was seen with calcium supplementation.

Fecal excretion of calcium (percentage of intake) decreased from $70 \%$ to $33 \%$ in group $B$ babies after calcium supplementation. Calcium retention rates $(\mathrm{mEq} / \mathrm{kg} / 24 \mathrm{hr})$ were similar in both groups initially but increased subsequently in group $B$ from 1.20 to $7.33 \mathrm{mEq} / \mathrm{kg} / 24 \mathrm{hr}$ and were 3 times as high in group $B$ than in group $A$ during the second and third balances.

Urinary phosphorus excretion was initially similar in both groups (group $A, 28.4 \pm 2.2 \mathrm{mg} / \mathbf{k g} / 24 \mathrm{hr} ;$ group $B, 32.4 \pm 5.5 \mathrm{mg} / \mathrm{kg} / 24$ hr), but decreased to half this value in infants of group $B$ after calcium supplementation had started $(P<\mathbf{0 . 0 2})$.

$G$ roup $B$ infants showed a higher percentage fecal fat excretion than group $A$ infants during the second and third balance.

In 9 of 10 paired radiographs of the knee and tibia group $B$ infants showed better defined bone texture and/or wider cortices than did group $A$ infants.

We suggest that prevention of the "bone disease of very low birth weight (VLBW) infants" may be accomplished by suitable calcium supplements.

\section{Speculation}

As a consequence of their special requirements and the unavailability of appropriately constituted infant formulas, infants born very prematurely fail to achieve intrauterine accretion rates for many minerals. Postnatal growth may also be jeopardized. We believe that for optimal postnatal growth infants born very prematurely require sufficient nutrients to parallel intrauterine accretion rates.

The VLBW infant, who is deprived of elements which normally 
accumulate in the last trimester of pregnancy, depends on an adequate supply of nutrients in the diet to allow him to grow at a rate similar to that in utero. In human milk and modified cow's milk formula several elements are present in insufficient quantities to permit accretion at intrauterine rates. Since calcium accumulates at an increasing rate in the last trimester $(29,38)$, the VLBW infant particularly is likely to become calcium deficient. The postnatal length growth of infants in our studies now approximates the intrauterine growth curve of Usher and McLean (35) and calcium acquisition rate presumably should also parallel that in utero.

If the VLBW infant is fed artificial milk formula currently available in an amount which supplies protein at the recommended rate of $4 \mathrm{~g} / \mathrm{kg} / 24 \mathrm{hr}(10)$ very large calcium deficits will result and will be manifested as deficient bone mineralization. Radiographs of appropriate for gestational age (AGA) VLBW infants aged 2-3 months frequently showed demineralization and poor matrix formation (26). In this investigation we have assessed the effects of giving these infants additional calcium lactate in an attempt to achieve a calcium retention rate similar to that in utero during the third trimester and to prevent this bone disease.

\section{PATIENTS, PROCEDURES, AND METHODS}

\section{PATIENTS}

We studied 30 infants of birth weight less than $1.3 \mathrm{~kg}$ who had no major respiratory or metabolic problems. Gestational age was assessed using the mother's last menstrual period and the scoring method of Dubowitz et al. (11): They were classified as either appropriate for gestational age (AGA) or small for gestational age (SGA), and assigned according to birth weight into three categories of less than 900,901-1100, and 1,101-1,300 g. They were then paired within these categories and were randomly allocated to one of two treatment groups. Infants ingroup $A$ received no calcium supplements, and infants in group $B$ received calcium lactate (40) $800 \mathrm{mg} / \mathrm{kg} / 24 \mathrm{hr}$ in divided doses mixed with each feed. All infants were fed "Improved" SMA-S26 (41) $200 \mathrm{ml} /$ $\mathrm{kg} / 24 \mathrm{hr}$, supplying approximately $160 \mathrm{cal} / \mathrm{kg} / 24 \mathrm{hr}$. All were given $0.3 \mathrm{ml}$ multivitamin preparation daily (42) containing $500 \mathrm{IU}$ vitamin $\mathrm{D}_{2}$. The total intake of vitamin $\mathrm{D}_{2}$ from the multivitamin preparation and formula ranged from 560 to 800 IU daily according to body weight.

Study of each infant started between days 14 and 21 of life depending on clinical status and formula intake, and terminated when the infant's weight reached $1.8 \mathrm{~kg}$ at a mean age of 54 days.

\section{PROCEDURES}

Each infant was weighed twice weekly on an Air Shields, Inc. (43) balance and the amount of formula given was adjusted accordingly. Body length (23) and head circumference were measured weekly. Skin fold thickness was determined weekly at three sites.

All infants were nursed in servocontrolled Isolettes (43), naked except for diapers, in an attempt to standardize their metabolic requirements.

Heel-prick blood samples were obtained twice weekly for $\mathrm{pH}$ and $\mathrm{PCO}_{2}$ determinations and the base excess was computed. Sodium bicarbonate was given orally if the base excess was greater than $1 \mathrm{SD}$ from the mean, i.e., greater than $-4.9 \mathrm{mEq} /$ liter. Venous blood was drawn weekly for determination of total and ionic calcium, phosphorus, magnesium, and total protein concentrations in plasma.

Intake and output balances of calcium, magnesium, phosphorus, and fat were carried out during this study. The first balance was done at 2-3 weeks of age, just before infants in group $B$ had started calcium supplements. Further balances were obtained at approximately 10-14-day intervals until the infant's weight reached $1.8 \mathrm{~kg}$. Each infant had a total of two to four balances, the number depending on initial weight and growth rate. Pair members usually had the same number of balances at approximately the same postnatal age. Stools were collected for $72 \mathrm{hr}$ and urine for $24 \mathrm{hr}$.

When each infant reached $1.8 \mathrm{~kg}$ weight a radiograph of the femur or tibia was taken on industrial fine grain film. The radiographs of each pair were assessed by Dr. B. J. Reilly, compared in a double blind fashion, and assigned to either calcium-supplemented or nonsupplemented groups. Also in double blind fashion cortical thickness was measured with microcalipers at six exactly defined sites and the mean ratio of cortical to total width of the bone at these sites was computed.

\section{CHEMICAL METHODS}

Blood $\mathrm{pH}$ and $\mathrm{P}_{\mathrm{CO}_{2}}$ were determined with a $\mathrm{pH}$ and blood gas analyzer (25) and the base excess computed from a SiggaardAndersen chart (31). Calcium ion activity in the plasma was determined under anaerobic conditions with a $\mathrm{Ca}^{++}$flow-through system and digital $\mathrm{pH}$ meter (27). Total calcium and magnesium concentrations were measured by emission and atomic absorption flame spectrophotometry $(1,20,44)$, respectively. Inorganic phosphorus was measured by the Gomori method (12) and total plasma protein concentration by the method of Lowry et al. (18), both on an automatic analyzer (45).

Individual stools were collected on tared plastic sheeting. The stools were pooled, weighed, and homogenized with a measured amount of deionized water. Urine volumes were measured and urine and stools frozen until chemical determinations were carried out. Stool was dry-ashed at $450^{\circ}$ for $72 \mathrm{hr}$ after addition of $1 \mathrm{ml}$ concentrated $\mathrm{H}_{2} \mathrm{SO}_{4} / \mathrm{g}$ stool suspension, the ash taken up in $10 \%$ $\mathrm{HNO}_{3}$ and diluted either with water for estimations of $\mathbf{P}$ or with "urine diluent" (1) for $\mathrm{Ca}$ and $\mathrm{Mg}$ estimations. Fecal fat was measured using the method of Van de Kamer et al. (36).

\section{RESULTS}

\section{BODY SIZE MEASUREMENTS}

The mean birth weights and gestational ages are summarized in Table 1. Mean birth weights did not differ between AGA and SGA, or between group $A$ and $B$ babies, but the mean gestational age was 3.5 weeks shorter in AGA than SGA babies $(P<0.001)$.

The average weekly weight gain was not different in groups $A$ and $B$ and showed a similar pattern in most infants. At the commencement of the study most of the smaller infants had passed the nadir of their postnatal weight loss, and the larger infants had regained their birth weight. The individual weight curves after approximately 3 weeks of age were parallel to the 3 rd centile intrauterine weight curve of Usher and McLean (35) until the infant reached approximately 36 weeks of gestational age, when the rate of weight gain accelerated in AGA infants. Average weekly weight gain was significantly less in infants whose birth weight was $<1 \mathrm{~kg}$ compared with those who were heavier at birth (Table 1).

Length increments between birth and age 14-21 days were less than in utero. Therefore, most AGA and all SGA infants entering the study had a length at or below the third centile. We found no significant difference in mean weekly length increments between groups $A$ and $B$, between AGA and SGA, and between infants of birth weight less than $1.0 \mathrm{~kg}$ and greater than $1.0 \mathrm{~kg}$. Average increments in head circumference and skinfold thickness did not differ significantly between the various subdivisions.

\section{CHEMICAL VALUES}

Because results were not significantly different in AGA and SGA infants, comparisons have been made only between groups $A$ and $B$.

Blood $\mathrm{pH}, \mathrm{P}_{\mathrm{CO}_{2}}, \mathrm{HCO}_{3}$, and Base Excess $(\mathrm{BE})$. The blood $\mathrm{pH}$ was similar in groups $A$ and $B$ during the third week of postnatal 
Table 1. Growth data: Man $\pm S E M$ and $t$ values (number in parentheses $=n$ )

\begin{tabular}{|c|c|c|c|c|c|c|}
\hline Group & Birth weight, $\mathrm{kg}$ & $\begin{array}{c}\text { Gestational age, } \\
\text { weeks }\end{array}$ & $\begin{array}{l}\text { Weight increment, } \\
\mathrm{g} / \text { week }\end{array}$ & $\begin{array}{l}\text { Length increment, } \\
\mathrm{cm} / \text { week }\end{array}$ & $\begin{array}{l}\text { Head circumference } \\
\text { increment, } \mathrm{cm} / \text { week }\end{array}$ & $\begin{array}{l}\text { Skinfold thickness } \\
\text { increment, } \mathrm{mm} / \text { week }\end{array}$ \\
\hline$A$ & $\begin{array}{c}0.981 \pm 0.046 \\
(16) \\
t=0.76\end{array}$ & $\begin{array}{c}29.9 \pm 0.6 \\
(16) \\
t=0.73\end{array}$ & $\begin{array}{c}163 \pm 6 \\
(16) \\
t=0.84\end{array}$ & $\begin{array}{c}1.08 \pm 0.04 \\
(16) \\
t=0.54\end{array}$ & $\begin{array}{c}1.12 \pm 0.03 \\
\quad(15) \\
t=1.20\end{array}$ & $\begin{array}{c}0.62 \pm 0.05 \\
\quad(16) \\
t=1.91\end{array}$ \\
\hline$B$ & $\begin{array}{c}1.032 \pm 0.048 \\
(14)\end{array}$ & $\begin{array}{c}30.6 \pm 0.7 \\
\quad(14)\end{array}$ & $\begin{array}{c}170 \pm 6 \\
(14)\end{array}$ & $\begin{array}{c}1.11 \pm 0.04 \\
(14)\end{array}$ & $\begin{array}{c}1.18 \pm 0.03 \\
(14)\end{array}$ & $\begin{array}{l}0.50 \pm 0.03 \\
\quad(14)\end{array}$ \\
\hline All SGA & $\begin{array}{c}1.01 \pm 0.060 \\
(13)\end{array}$ & $\begin{array}{l}32.2 \pm 0.4 \\
(13)\end{array}$ & $\begin{array}{r}170 \pm 7 \\
(13)\end{array}$ & $\begin{array}{c}1.08 \pm 0.04 \\
(13)\end{array}$ & $\begin{array}{c}1.14 \pm 0.04 \\
(13)\end{array}$ & $0.53 \pm 0.05$ \\
\hline $\begin{array}{l}\text { All }<1 \mathrm{~kg} \text { birth } \\
\text { weight }\end{array}$ & & & $\begin{array}{c}156 \pm 4 \\
\quad(17) \\
t=3.28^{2}\end{array}$ & $\begin{array}{c}1.06 \pm 0.04 \\
\quad(17) \\
t=1.42\end{array}$ & $\begin{array}{c}1.13 \pm 0.03 \\
(16) \\
t=0.11\end{array}$ & $\begin{array}{c}0.54 \pm 0.03 \\
\quad(17) \\
t=0.42\end{array}$ \\
\hline
\end{tabular}

${ }^{1} P<0.01$.

${ }^{2} P<0.001$.

age (Fig. 1) when the study started. It then rose in infants of group $A$, whereas it remained unchanged in babies of group $B$, so that at the end of the study a significant difference between groups had developed. The $\mathrm{P}_{\mathrm{CO}_{2}}$ was higher initially in group $A$ than in $B$ infants and decreased significantly in the former but not in the latter. Hypercarbia $\left(\mathrm{P}_{\mathrm{CO}_{2}}>50 \mathrm{~mm} \mathrm{Hg}\right)$ occurred in four group $A$ and seven group $B$ babies but was usually of short duration and not severe. Of the group $B$ infants only two developed prolonged episodes of hypercarbia, and in these the highest level $(63 \mathrm{~mm} \mathrm{Hg})$ was present before calcium supplementation had started. A value of 50 or $51 \mathrm{~mm} \mathrm{Hg}$ was observed on one occasion in all other group $B$ infants, and one group $A$ baby had also a rather prolonged episode of hypercarbia. No significant differences in bicarbonate were observed in the two groups of infants throughout the study. The base excess was similar initially but decreased more in group $A$ than in $B$ babies. This difference was statistically significant only shortly after caicium lactate therapy had begun in group $B$ babies. Of the 14 group $A$ babies, 6 did not develop metabolic acidosis (BE $>-4.9 \mathrm{mEq}$ /liter). Two group $A$ infants developed a significant (46) degree of metabolic acidosis at least once during the study period, whereas in the other six, the degree of acidosis was less and seen only sporadically. All AGA babies in the B group developed some degree of metabolic acidosis. After calcium supplementation had started, 22 episodes of "late metabolic acidosis" occurred, of which half were mild (BE between -5 and $-6.6 \mathrm{mEq}$ ); $\mathrm{BE}$ was in excess of $-8.3 \mathrm{mEq} /$ liter in less than $20 \%$ of the episodes.

Plasma Calcium (Free and Total). Table 2 shows that ionic calcium values were similar in both groups before calcium-supplementation started in group $B$, and remained so during the study except for the last sample. The last values in group $B$ were slightly higher than the first, but this was not statistically significant on paired $t$-test $(P<0.1)$.

Ionic hypercalcemia $(>2.70 \mathrm{mEq} /$ liter $)$ occurred in three group $A$ and eight $B$ babies. In two patients (one group $A$, one group $B$ ) the ionic hypercalcemia occurred in the first specimen and in five instances in group $B$ babies the single high value was seen in the second specimen, which was drawn after calcium supplementation had just started. The highest value observed was $2.88 \mathrm{mEq} /$ liter and was associated with a total calcium concentration of 5.76 $\mathrm{mEq} /$ liter, also in the hypercalcemic range. In two group $B$ infants the ionic hypercalcemia recurred after 14 days.

Ionic hypocalcemia $(<2.20 \mathrm{mEq} /$ liter $)$ occurred in seven patients of group $A$ and six patients of group $B$, but was never severe.

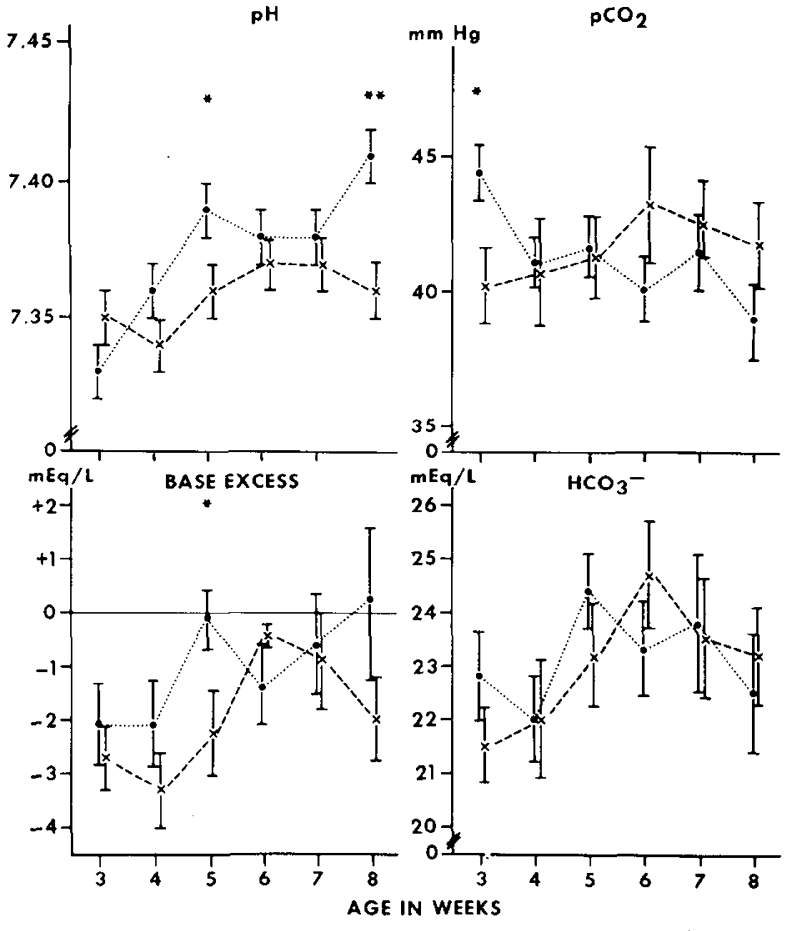

Fig. 1. Blood $\mathrm{pH}, \mathrm{PCO}_{2}$, base excess, and bicarbonate concentrations. .... group $A ; \times---\times$ : group $B$. Each point represents mean \pm SEM of at least 10 observations. ${ }^{*}: P<0.05 ;{ }^{* *}: P<0.01$.

It was seen even in babies of group $B$ after calcium supplementation had started. No association between blood $\mathrm{pH}$ and ionic hypocalcemia could be detected, but total calcium values were either slightly subnormal $(<4.00 \mathrm{mEq} /$ liter $)$ or in the lower third of the normal range.

Total calcium values did not differ between groups initially, but were slightly higher after calcium supplementation had started in group $B$. Hypercalcemia ( $>5.50 \mathrm{mEq} /$ liter) occurred only once.

Plasma Total Magnesium. Mean plasma magnesium levels of groups $A$ and $B$ infants were similar in the initial specimen, but in the second specimen the levels were significantly lower in group $B$. 
Table 2. Plasma chemical values: Mean \pm SEM (number in parentheses $=n$ )

\begin{tabular}{|c|c|c|c|c|c|c|}
\hline Sample No. & $\begin{array}{c}\text { Postnatal age, } \\
\text { days }\end{array}$ & $\mathrm{Ca}^{2+}, \mathrm{mEq} /$ liter & $\begin{array}{l}\text { Total Ca, } \\
\mathrm{mEq} / \text { liter }\end{array}$ & $\mathrm{Mg}, \mathrm{mEq} /$ liter & $P_{i}, m g / 100 m l$ & Protein, $\mathrm{g} / 100 \mathrm{ml}$ \\
\hline \multicolumn{7}{|l|}{ First } \\
\hline$B$ & $19.4 \pm 1.3$ & $\begin{array}{c}2.42 \pm 0.06 \\
(13)\end{array}$ & $\begin{array}{c}4.72 \pm 0.12 \\
(13)\end{array}$ & $\begin{array}{c}1.84 \pm 0.03 \\
(13)\end{array}$ & $\begin{array}{c}6.87 \pm 0.26 \\
(13)\end{array}$ & $\begin{array}{c}4.39 \pm 0.22 \\
(13)\end{array}$ \\
\hline \multicolumn{7}{|l|}{ Second } \\
\hline$B$ & $27.2 \pm 1.4$ & $\begin{array}{c}2.44 \pm 0.07 \\
\quad(13)\end{array}$ & $\begin{array}{c}4.82 \pm 0.12] \\
\text { (13) }\end{array}$ & $\begin{array}{c}1.72 \pm 0.02] \\
(13)\end{array}$ & $\begin{array}{c}6.50 \pm 0.17] \\
(15)\end{array}$ & $\begin{array}{c}4.54 \pm 0.14 \\
\text { (13) }\end{array}$ \\
\hline \multicolumn{7}{|l|}{ Last } \\
\hline$A$ & $52.4 \pm 3.1$ & $\left.\begin{array}{c}2.40 \pm 0.05 \\
(16)\end{array}\right]$ & $\begin{array}{c}4.57 \pm 0.11 \\
(16)\end{array}$ & $\begin{array}{c}1.74 \pm 0.05 \\
(16)\end{array}$ & $\begin{array}{c}6.36 \pm 0.23 \\
(15)\end{array}$ & $\begin{array}{c}4.60 \pm 0.18 \\
\quad(13)\end{array}$ \\
\hline
\end{tabular}

${ }^{1} P<0.05$.

${ }^{2} P<0.01$.

Paired $t$-testing within the same group showed that the first value was significantly higher than later values, whereas in group $A$ this trend was not apparent. All values fell within the accepted normal range for adults $(1.4-2.0 \mathrm{mEq} /$ liter $)$.

Plasma Inorganic Phosphorus. Mean plasma inorganic phosphorus values did not differ between groups in the initial sample. After calcium supplementation had started, group $B$ showed significantly lower mean values than group $A$ in the second and third specimens; thereafter, mean values did not differ between groups.

Total Plasma Protein. Mean plasma protein concentrations did not differ between groups, or between early and late specimens. Individual values were as low as $2.8 \mathrm{~g} / 100 \mathrm{ml}$ and approximately $20 \%$ of the total values were below $4 \mathrm{~g} / 100 \mathrm{ml}$.

\section{INTAKE AND OUTPUT MEASUREMENTS}

Calcium. The results of calcium balances are depicted on Figure 2. Mean urinary calcium excretion rates (panel $I$ ) did not differ between groups $A$ and $B$, and no increase was seen in group $B$ infants after calcium supplementation had started. Temporary hypercalciuria $(>0.3 \mathrm{mEq} / \mathrm{kg} / 24 \mathrm{hr})(9,17)$ occurred on eight occasions in six patients, three in group $A$ and five in group $B$, in two of whom it was seen before as well as after institution of calcium supplementation.

Fecal excretion rates of calcium (panel $I I$ ) were similar in groups $A$ and $B$ infants before calcium supplement was started in group $B$ and averaged $70 \%$ of the amount ingested. In group $A$, fecal calcium excretion decreased only in the third balance $(P<0.01)$, whereas in group $B$ the percentage decrease was already highly significantly different between the first and second balances $(P<$ 0.001 ).

All infants, except three, were in positive calcium balance during the control period when both groups showed similar average net retention rates of $1.5 \mathrm{mEq} / \mathrm{kg} / 24 \mathrm{hr}$. However, on subsequent balances, calcium retention rates varied significantly between groups $A$ and $B$. In infants of group $A$ the rate rose only gradually and paired $t$-testing showed the differences to be much less significant than in group $B(P<0.05$ when first and third balances were compared; $P<0.02$ when first and fourth were compared in group $A$ ). In group $B$ the net retention rate of calcium rose rapidly after calcium supplementation had started $(P<0.001$ between first and subsequent balances); mean net retention rates of calcium were similar to the intrauterine accretion rate of calcium.

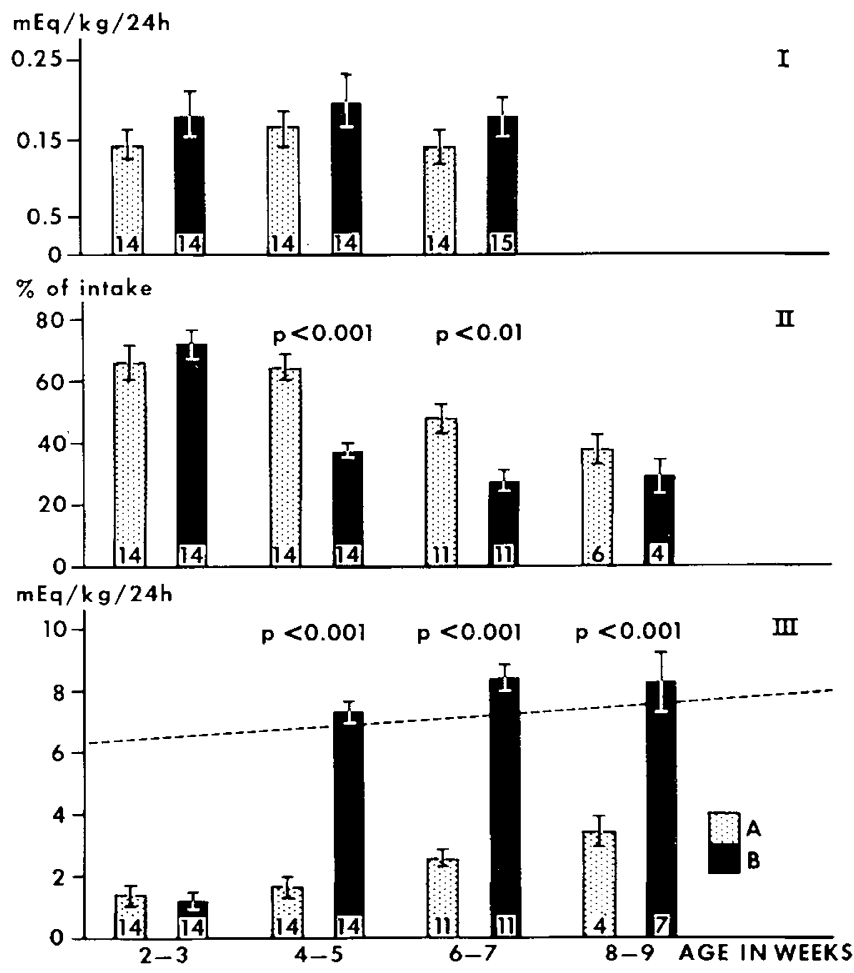

Fig. 2. Calcium balances. Each column represents mean \pm SEM. Numeral in each column $=n$. $I$ : urinary calcium excretion rate. $I I$ : fecal calcium excretion as percentage of intake; $I I I$ : net calcium retention. The interrupted line indicates the intrauterine accretion rate of calcium (29).

Magnesium. Urinary magnesium excretion was similar in both groups of infants throughout the study, and was not affected by calcium supplementation (Fig. 3, panel I). During the initial balance, approximately $45 \%$ of the ingested magnesium was excreted in the stool (panel $I I$ ). The percentage fecal magnesium decreased with increasing age, significantly in group $A(P<$ $0.005)$. Infants in both groups retained similar amounts of magnesium and showed increased retention with increasing age (panel IIII). When retention rate was related to body weight, this 


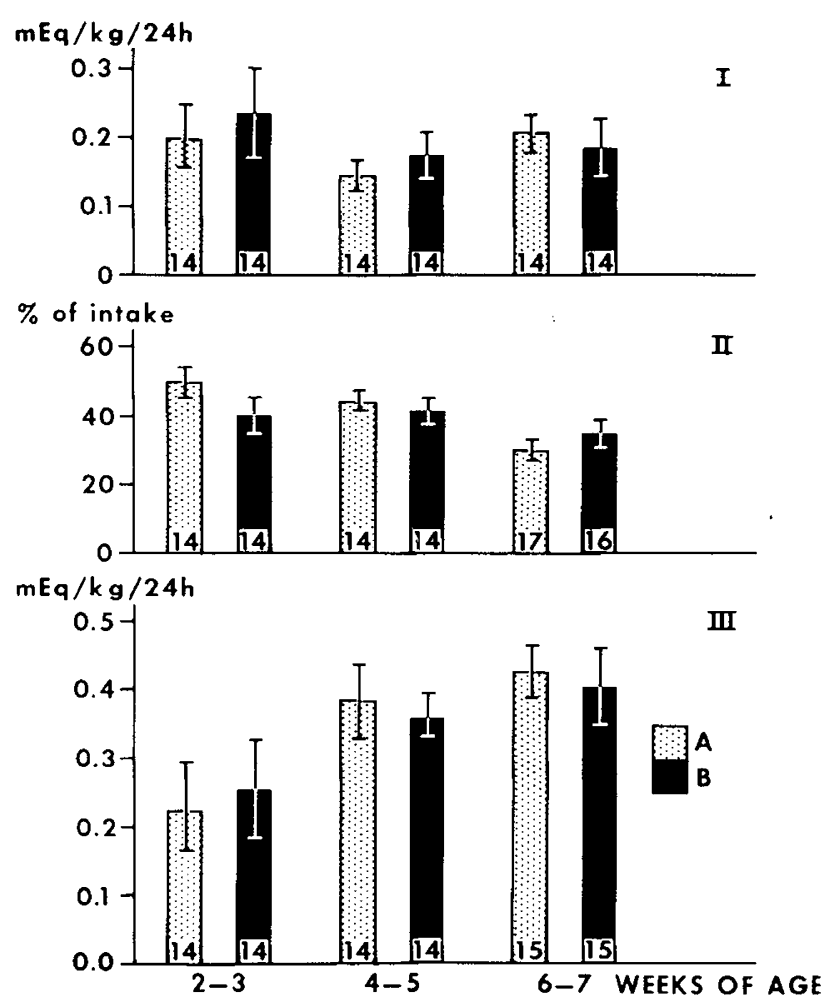

Fig. 3. Magnesium balances. Each column represents mean \pm SEM. Numeral in each column $=n$. $I$ : urinary magnesium excretion rate; $I I$ : fecal magnesium excretion as percentage of intake; III: net magnesium retention.

increase was statistically significant only in group $A$ babies (paired and intragroup $t$ value $<0.025$ between first and third balances).

Phosphorus. Urinary phosphorus excretion was similar in both groups initially and averaged $30 \mathrm{mg} / \mathrm{kg} / 24 \mathrm{hr}$ (Fig. 4, panel I). In group $A$ infants it did not change significantly with increasing age, but in group $B$ infants a $50 \%$ reduction occurred after the introduction of supplemental calcium $(P<0.02)$. Fecal phosphorus excretion as a percentage of intake was also similar in the two groups initially (panel $I I$ ), but differed significantly during later balances with group $B$ infants showing higher values $(P<$ $0.05)$. Mean phosphorus retention was similar in both groups (panel III), increased with advancing age, but in group $B$ increased retention occurred as soon as calcium supplementation had started (group $A$ first $v s$ third balance $P<0.01$; group $B$ first $v s$ second balance $P<0.01$ ).

Fat. Fat retention (grams per kilogram per $24 \mathrm{hr}$ ) increased by $20 \%$ in group $A$ babies from the first to third balance and by approximately $13 \%$ in group B infants (Fig. 5, panel I). However, differences were not statistically significant, either within groups with age or between groups. Fat absorption as percent of intake increased between the second and third balance in group $A$ babies but remained unchanged in group $B$ infants (panel $I I$ ). During the second and third balance mean values were significantly higher in group $A$ than in group $B(P<0.025$ second balance; $P<0.01$ third balance).

\section{RADIOGRAPHIC ASSESSMENT}

In 9 of 10 pairs assessment of bone texture and cortical thickness enabled the infants to be assigned correctly to group $A$ or $B$. The bone texture was better defined and/or the cortices were somewhat wider in group $B$ infants than in group $A$ infants. Figure 6 shows the difference in both cortical thickness and bone texture in the knees of one of the pairs of infants. No difference between groups $A$ and $B$ was detected in one pair in which the group $B$ infant had received supplemental calcium for only 8 days. On paired $t$-testing

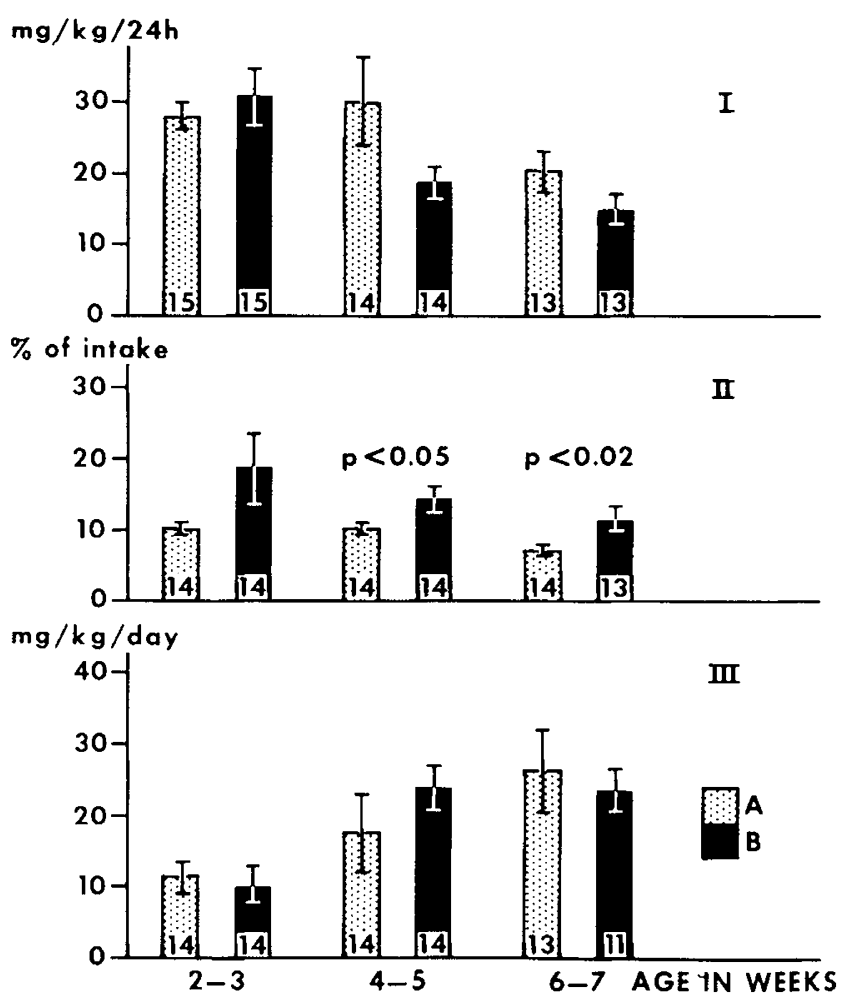

Fig. 4. Phosphorus balances. Each column represents mean \pm SEM. Numeral in each column $=n$. I: urinary phosphorus excretion rate; II: fecal phosphorus excretion as percentage of intake; III: net phosphorus retention.

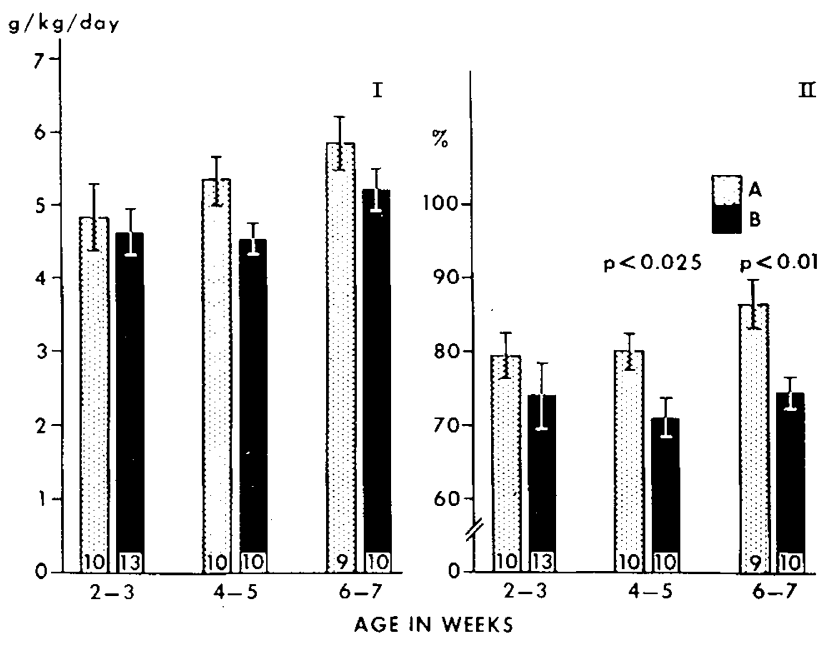

Fig. 5. Fat balances. Each column represents mean \pm SEM. Numeral in each column $=n$. $I$ : fat retention; $I I$ : fat absorption as percent of intake.

the ratios of cortical thickness to total bone diameter was higher in group $B$ than in group $A$ infants $(P<0.05)$.

\section{DISCUSSION}

The difficulties of achieving adequate nutrition in the VLBW infant have been reviewed by Shaw $(29,30)$. Requirements differ from those of the full term infant because the VLBW infant will miss the acquisition of nutrients which normally occurs in the last trimester of pregnancy. Calcium accumulates in the human fetus at a rate increasing from $5.2 \mathrm{mEq} / \mathrm{kg} / 24 \mathrm{hr}$ at 28 weeks to 7.5 $\mathrm{mEq} / \mathrm{kg} / 24 \mathrm{hr}$ at 36 weeks postconceptional age (29). Human milk contains approximately $22 \mathrm{mEq} /$ liter calcium and most com- 


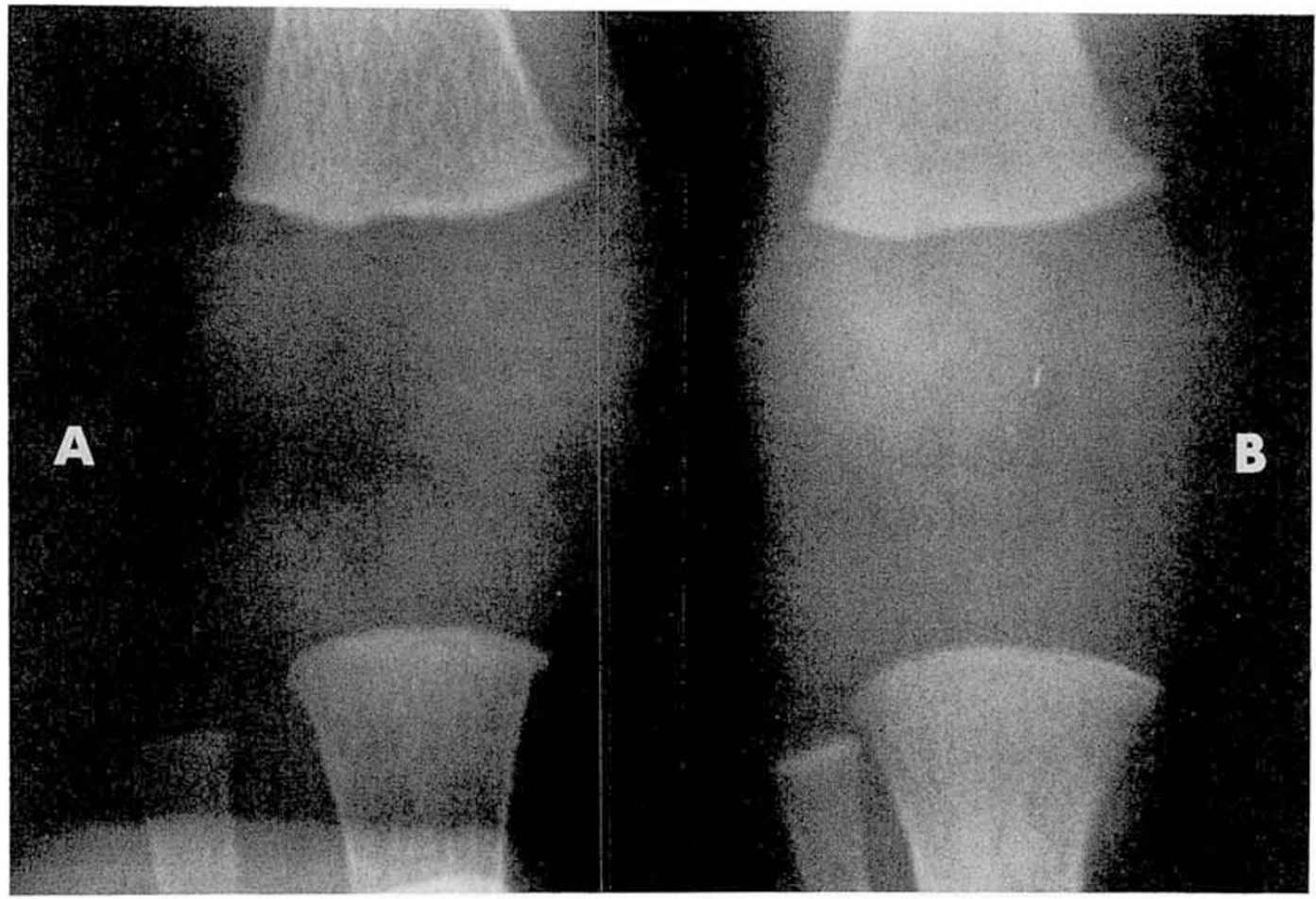

Fig. 6. Radiographs of the knee in one pair of infants. Note in $A$ the coarse trabeculation indicating lack of bone mass per unit volume (osteoporosis) compared with $B$. Note also the difference in cortical thickness best seen in the lateral tibia.

mercial "humanized" cow's milk formulas contain similar amounts. Thus, if the infant, being fed formula at $200 \mathrm{ml} / \mathrm{kg} / 24$ $\mathrm{hr}$, absorbs $100 \%$ of the calcium he will acquire $4-5 \mathrm{mEq} / \mathrm{kg} / 24$ hr. However, not all of the available calcium will be absorbed; if the absorption rate were $50 \%$, a VLBW infant of 28 weeks of gestation receiving standard formula would have a calcium deficit of over $7 \mathrm{~g}$ by 40 weeks postconceptional age (equivalent to one-quarter his total body calcium). This cumulative calcium deficit will be manifested by bone demineralization.

In a previous series of infants studied by us (26), bone demineralization became marked at the age of 6-7 weeks. Other reports in the literature (13) also indicate the occurrence of bone demineralization in premature infants.

In this study, the infants fed supplemental calcium achieved calcium retention rates similar to intrauterine rates and appropriate to their gain in length. This greater retention rate was reflected in the better texture and wider cortex of bones. Further suggestive evidence for increased mineral incorporation was the reduction of plasma phosphorus and magnesium and a tendency to reduction of urinary phosphorus after calcium supplementation.

Retention rates of calcium similar to those in utero have rarely been observed in the VLBW infant. Sutton and Barltrop (34) found average retention rates of $50 \mathrm{mg} / \mathrm{kg} / 24 \mathrm{hr}$ in four premature infants. Hövels et al. (15) reported mean retention rates approach ing those of the present study only in infants fed cow's milk to which calcium had been added. Also Benjamin et al. (3) found comparable retention rates only in infants fed cow's milk. However, all these studies include few or no VLBW infants comparable in birth weight to those in our series. Shaw (30) measured calcium and fat absorption in infants of birth weight and postconceptional age similar to infants in the present study and observed cumulative deficits.

The increase in percentage calcium absorption by infants after starting supplemental calcium contrasts with the finding in experimental animals (4) and in adult man $(21,33)$, where a low calcium diet results in a high percentage absorption and vice versa. In general, absorption of calcium is related to total body calcium stores rather than to plasma calcium concentrations (4). Intestinal mechanisms which influence adaptation to a calcium-deficient diet are stimulation of calcium binding protein formation (37), increase in $\mathrm{Ca}^{++}$ATPase activity (28), and the increased formation of active vitamin D metabolites (24). The latter mechanism is influenced by calcium content of the renal cell: decreased calcium leads to increased 1,25-dihydroxycholecalciferol formation, whereas increased calcium increases the formation of the relatively inactive 24,25-dihydroxy derivative of vitamin D (5). No information is available about the age at induction of these mechanisms or whether they are present at birth in the human. The progressive increase in efficiency of calcium absorption seen in group $A$ infants after the age of 4-5 weeks may relate to maturation of vitamin D hydroxylases in liver and kidney and induction of $\mathrm{Ca}$ binding protein in the gut.

Potential adverse effects of excessive calcium lactate administration are hypercalcemia, hypercalciuria, hypophosphatemia, decreased fat and phosphorus absorption, hypercarbia, and metabolic acidosis.

Growth rate, which may be depressed in hypercalcemia (6), was not decreased in the calcium-supplemented group.

The incidence and severity of ionic hypercalcemia were not increased in the calcium-supplemented infants, although the mean plasma calcium value was somewhat higher than that in nonsupplemented babies at the end of the study. Hypercalciuria, as defined by Cuisinier-Gleizes et al. (9) and Knapp (17), occurred with similar frequency in both groups of infants and was not influenced by calcium supplementation.

The influence of calcium on phosphate absorption from the gut is partially dependent on the $\mathrm{Ca} / \mathrm{P}$ ratio in the diet (19). Phosphate absorption is enhanced by increasing calcium concentration in the diet (33) and calcium absorption increased by increasing the dietary phosphate concentration (39) until a $\mathrm{Ca} / \mathrm{P}$ ratio of $2: 1$ is reached. The higher fecal phosphorus content in group $B$ infants after calcium supplementation was compensated for by decreased urinary phosphorus losses. This resulted in similar phosphorus retention rates for both groups of infants. However, all infants showed phosphorus retention rates below those in utero $(29,38)$.

The relatively high urinary phosphate excretion in the noncalcium-supplemented infants may be related to the relatively low calcium intake which may stimulate parathormone secretion, 
which in turn will decrease the renal tubular reabsorption of phosphate (8). If enoligh calcium is supplied, as in the group $B$ babies, then excessive parathyroid stimulation would cease and the renal tubular reabsorption of phosphate increase.

Loss of calcium and of fat in the stools has been shown to be interrelated $(7,14,32)$. Not only are high fat intakes associated with decreased calcium absorption rates from the gut, but also high calcium intakes may lead to reduced fat absorption. Furthermore, the fatty acid composition of the formula will influence the efficiency of calcium absorption $(2,14)$. Unlike findings in control infants the percentage fat absorption in group $B$ did not increase with postnatal age so that a significant difference was seen in the second and third balance. However, the quantitative difference was insufficient to interfere with growth.

A minor, but statistically significant difference was observed in blood $\mathrm{pH}$ and negative base excess after institution of calcium lactate supplementation. Calculation of plasma ionic balance in some infants suggested that this difference was caused by the lactate. Hydrogen ion released as a result of calcium deposition in bone (16) could also partially account for the $\mathrm{pH}$ difference. However, $\mathrm{pH}$ and base excess values in the infants in our study were similar to those reported in premature infants by Manzke and Nolte (22).

Thus, of the potential adverse effects of calcium supplementation with calcium lactate only the effect on fat absorption was observed. In view of this finding and the unexpected increase in percentage of absorption of calcium with a high calcium intake, we have used a calcium lactate supplement of $600 \mathrm{mg} / \mathrm{kg} / 24 \mathrm{hr}(5.5$ $\mathrm{mEq} \mathrm{Ca}$ ) in recent studies.

\section{SUMMARY}

By giving a supplement of calcium lactate, $800 \mathrm{mg} / \mathrm{kg} / 24 \mathrm{hr}$ (equal to $147 \mathrm{mg} / \mathrm{kg} / 24 \mathrm{hr}$ calcium), to VLBW infants a calcium retention rate equivalent to the intrauterine acquisition rate was achieved. This increased rate was reflected radiographically in improved bone formation and wider cortices. The percentage absorption of calcium was unexpectedly high in comparison with a control group of infants. Growth rate was unchanged and the only side effects observed were slight reductions in blood $\mathrm{pH}$, and fat and phosphorus absorption compared with the control group. In view of the low calcium content of currently available infant formulas it appears reasonable and safe to give calcium supplementation to allow a retention rate appropriate to the growth and postconceptional age of the baby.

\section{REFERENCES AND NOTES}

1. Alcock, N., Macintyre, I., and Radde, I.: The determination of magnesium in biological fluids and tissues by flame spectrophotometry. J. Clin. Pathol. 13: $506(1960)$.

2. Barltrop, D., and Oppe, T. E.: Absorption of fat and calcium by low birthweight infants from milks containing butterfat and olive oil. Arch. Dis. Childhood, 48 : 496 (1973)

3. Benjamin, H. R., Gordon, H. H., and Marples, E.: Calcium and phosphorus requirements of premature infants. Amer. J. Dis. Child., 65: 412 (1943).

4. Benson, J. D., Emery, R. S., and Thomas, J. W.: Effects of previous calcium intakes on adaptation to low and high calcium diets in rats. J. Nutr., 97: 53 (1969).

5. Boyle, I. T., Gray, H. F., and DeLuca, H. F.: Regulation by calcium of in vivo synthesis of 1,25-dihydroxycholecalciferol and 21,25-dihydroxycholecalciferol Proc. Nat. Acad. Sci. U.S.A., 68: 2131 (1956).

6. British Paediatric Association Committee on Hypercalcaemia: Hypercalcaemia in infants and vitamin D. Brit. Med. J., 2: 149 (1971).

7. Cheng, A. L. S., Morehouse, M. G., and Deuel, H. J., Jr.: The effect of the level of dietary calcium and magnesium on the digestibility of fatty acids, simple triglycerides, and some natural and hydrogenated fats. J. Nutr., 37: 237 (1949).

8. Clark, I.: Dietary regulation of parathyroid activity. In: R. V. Talmage and L. F Belanger: Parathyroid hormone and thyrocalcitonin (calcitonin), p. 428 Proceedings of the Third Parathyroid Conference, Montreal, October, 1967 (Excerpta Medica, Amsterdam, 1968).

9. Cuisinier-Gleizes, P., Mathieu, H., and Royer, P.: Physiologie de l'excretion renale du calcium. Pathol. Biol., 11: 222 (1963).

10. Davidson, M.: Formula feeding of normal term and low birth-weight infants. Pediat. Clin. N. Amer., 17: 913 (1963)
11. Dubowitz, L. M. S., Dubowitz, V., and Goldberg, G.: Clinical assessment of gestational age in the newborn infant. J. Pediat. 77: 1 (1970).

12. Gomori, G.: A modification of the colorimetric phosphorus determination for use with the photoelectric colorimeter. J. Lab. Clin. Med., 27: 955 (1942).

13. Griscom, N. T., Craig, J. N., and Neuhauser, E. B. D.: Systemic bone disease developing in small premature infants. Pediatrics, 48: 883 (1971).

14. Hanna, F. M., Navarrete, D. A., and Hsu, F. A.: Calcium-fatty acid absorption in term infants fed human milk and prepared formulas simulating human milk. Pediatrics, 45: 216 (1970).

15. Hövels, O., Thilenius, O. G., and Krafczyk, S.: Untersuchungen zum Calciumund Phosphatstoffwechsel Frühgeborener. I. Mitteilung. Der Eingfluss des Angebotes, der Grundnahrung und des Calciumphosphorquotienten der Zufuhr auf die Calcium-retention. Z. Kinderheilk., 83: 508 (1960).

16. Kildeberg, P., Engel, K., and Winters, R. W.: Balance of net acid in growing infants. Acta Paediat. Scand., 58: 321 (1969).

17. Knapp, E. L.: Factors influencing the urinary excretion of calcium. 1. In normal persons. J. Clin. Invest., 26: 182 (1947).

18. Lowry, O. H., Rosebrough, N. J., Farr, A. L. and Randall, R. J.: Protein measurement with the Folin phenol reagent. J. Biol. Chem., 193: 265 (1941).

19. Lutwak, L., Laster, L., Gitelman, H. J., Fox, M., and Whedon, G. D.: Effects of high dietary calcium and phosphorus on calcium, phosphorus, nitrogen and fat metabolism in children. Amer. J. Clin. Nutr., 14: 76 (1964)

20. MacIntyre, I.: Flame photometry. Advan. Clin. Chem., 4: 1 (1961).

21. Malm, O.: Adaptations to alterations in calcium intake. In: R. H. Wasserman: The Transfer of $\mathrm{Ca}$ and $\mathrm{Sr}$ Across Biological Membranes (Academic Press, New York, 1963).

22. Manzke, H., and Nolte, H.: Untersuchungen des Säure-Basen-Status bei Frühgeborenen. Z. Kinderheilk., 102: 250 (1968).

23. Miller, H. C., and Hassanein, K.: diagnosis of impaired fetal growth in newborn infants. Pediatrics, 48: 511 (1971).

24. Omdahl, J. L., and Thornton, P. A.: Intestinal calcium absorption and calcium-binding protein: Influence of dietary calcium. Proc. Soc. Exp. Biol. Med., I39: 975 (1972).

25. Owen-Thomas, J. B., Ulan, O. A., and Swyer, P. R.: The effect of varying inspiratory gas flow rate on arterial oxygenation during IPPV in the respiratory distress syndrome. Brit. J. Anaesthesiol., 40: 493 (1968).

26. Radde, I. C., Chance, G. W., Bailey, K., O'Brien, J., Day, G. M., and Sheepers, J.: Effects of correction of late metabolic acidosis on growth and minerals in very low birthweight $(<1.3 \mathrm{~kg})$ infants (VLBW). Pediat. Res., 7: 170 (1973).

27. Radde, I. C., Hoffken, B., Parkinson, D. K., Sheepers, J., and Luckham, A.: Practical aspects of a measurement technique for calcium ion activity in plasma. Clin. Chem., 17: 1003 (1971).

28. Radde, I. C., Parkinson, D. K., and Shami, Y.: The calcium pump in renal, intestinal and placental plasma membranes; The effect of calcitonin (CT), parathyroid extract (PTE) and vitamin D, Vol. III, pp. 123. Proceedings of the Thirteenth International Congress on Paediatrics, Vienna, 1971.

29. Shaw, J. C. L.: Parenteral nutrition in the management of sick low birth weight infants. Pediat. Clin. N. Amer., 20: 333 (1973).

30. Shaw, J. C. L.: Malnutrition in premature infants. Proc. Nutr. Soc., 33: 103 (1974).

31. Siggaard-Andersen, O., Engel, K., Jørgensen, K., and Astrup, P.: A micromethod for determination of $\mathrm{pH}$, carbon dioxide tension, base excess and standard bicarbonate in capillary blood. Scand. J. Clin. Lab. Invest., 12: 172 (1960).

32. Southgate, D. A. T., Widdowson, E. M., Smiths, B. J., Cooke, W. T., Walker, C. H. M., and Mathers, N. P.: Absorption and excretion of calcium and fat by young infants. Lancet, $i: 487$ (1969).

33. Spencer, H., Lewin, I., Fowler, J., and Samachson, J.: Influence of dietary calcium intake on Ca ${ }^{47}$ absorption in man. Amer. J. Med., 46: 197 (1969).

34. Sutton, A., and Barltrop, D.: Absorption, accretion and endogenous faecal excretion of calcium by the newborn infant. Nature, 242: 265 (1973).

35. Usher, R., and McLean, F.: Intrauterine growth of live-born Caucasian infants at sea level: 'Standards obtained between measurements in 7 dimensions of infants born between 25 and 44 weeks of gestation. J. Pediat., 74: 901 (1969).

36. Van de Kamer, J. H., Ten Bokkel Huinink, H., and Weijers, H. A.: Rapid method for the determination of fat in feces. J. Biol. Chem, 177: 347 (1949)

37. Wasserman, R. H., and Taylor, A. N.: Evidence for a vitamin $D_{3}$-induced calcium-binding protein in New World primates. Proc. Soc. Exp. Biol. Med., 136: 25 (1971).

38. Widdowson, E. M.: The fetus and neonate. In: N. S. Assali. Biology of Gestation. Vol. II (Academic Press, New York, 1968).

39. Widdowson, E. M., McCance, R. A., Harrison, G. E., and Sutton, A.: Effect of giving phosphate supplements to breast-fed babies on absorption and excretion of calcium, strontium, magnesium, and phosphorus. Lancet, ii: 1250 (1963).

40. Calcium lactate solution, $100 \mathrm{mg} / \mathrm{ml}$.

41. SMA-S26 Wyeth Ltd., Downsview, Ontario. Manufacturer's composition of formula: fat $4.3 \%$; carbohydrates $8.6 \%$; protein $1.8 \%$; Cal $80 / \mathrm{dl} ; \mathrm{Na}^{+} 0.8$ $\mathrm{mEq} / \mathrm{dl} ; \mathrm{K}^{+} 1.7 \mathrm{mEq} / \mathrm{dl} ; \mathrm{Cl} 1.1 \mathrm{mEq} / \mathrm{dl} ; \mathrm{Ca} 50 \mathrm{mg} / \mathrm{dl} ; \mathrm{P} 37 \mathrm{mg} / \mathrm{dl} ; \mathrm{Mg} 6$ $\mathrm{mg} / \mathrm{dl}$.

42. ABDEC, Parke, Davis \& Co. Ltd., Toronto, Ontario.

43. Air Shields (Canada) Ltd., Downsview, Ontario.

44. Unicam SP 1900, Pye Unicam Ltd., Cambridge, England.

45. Model 1512, Carlo Erba SPA, Scientific Instruments Division, Milano, Italy.

46. $\mathrm{BE}$ in excess of $-8.3 \mathrm{mEq} /$ liter ( $>3 \mathrm{SD}$ of mean).

47. The authors wish to thank Miss A. Zitman, R. N., for her assistance in specimen collection, recording of clinical data and supervision of balance studies; Mrs. 
D. Hanimyan, B.Sc., Mr. J. Fabenyi, R. T., B.Agr., and Mr. M. Khan, for their expert technical assistance. The authors are grateful to the Medical and Nursing Staff of the Neonatal Unit of the Hospital for Sick Children for their help and co-operation.

48. This investigation was in part supported by the Medical Research Council of
Canada (Grant MA 4635)

49. Requests for reprints should be addressed to: 1. C. Radde, M.D., Research Institute, The Hospital for Sick Children, 555 University Ave., Toronto 2 (Canada)

50. Accepted for publication April 2, 1975

\title{
The Determination of Hypoxanthine and Xanthine with a $\mathrm{Po}_{2}$ Electrode
}

\author{
O. D. SAUGSTAD ${ }^{(18)}$ \\ Perinatal Research Unit, University Hospital, Uppsala, Sweden
}

\section{Extract}

A simple and rapid method for determination of the hypoxanthine and xanthine concentration in plasma and urine is described. The method is based on the principle that oxygen is consumed quantitatively when hypoxanthine and xanthine are oxidized to urate by xanthine oxidase. By using Henry's law a direct measure of the hypoxanthine and xanthine concentration is obtained.

The method determines these oxypurines in volumes of $200 \mu \mathrm{l}$ in concentrations less than $5 \mu \mathrm{mol} /$ liter in about $5 \mathrm{~min}$. The average precision in the range of $0-50 \mu \mathrm{mol} /$ liter is $2.6 \mu \mathrm{mol} /$ liter. Of the added hypoxanthine, $99-102 \%$ is recovered in plasma. Even though xanthine oxidase is a rather nonspecific enzyme, experiments show that this method is highly specific during physiologic conditions.

\section{Speculation}

Other purines which can be metabolized to hypoxanthine can be determined by this method. For instance, inosine, which is metabolized to hypoxanthine by nucleoside phosphorylase in the presence of phosphate, might also be determined according to this method.

The spectrophotometric method of Kalckar (10) represented an important step in the determination of the purine metabolites, hypoxanthine and xanthine. The principle of this method was employed together with further developments of $\mathrm{J} \phi$ rgensen $e t$ al. (8), and Brandt Petersen et al. (3). In addition there are also chromatographic and isotope methods available for determination of these oxypurines (13).

However, all of these methods are unsuitable for routine determination because they are time consuming, demand large volumes of blood, and are inaccurate for the detection of the low concentrations of oxypurines found in human plasma.

Berne (1) showed that there is an increased level of inosine and hypoxanthine in coronary venous blood from the ischemic myocardium of cat and dog. Crowell et al. (5) showed that dogs lose their purines irreversibly during hemorrhagic shock. Saugstad (12) showed that the oxypurine level in umbilical cord plasma is increased in newborn infants with clinical signs of intrauterine hypoxia.

Collectively, these results indicate the need for a simple, reliable, rapid method for the measurement of oxypurines in the low concentrations found in human plasma. The present report describes such a method.

\section{THEORY}

Hypoxanthine is oxidized to urate via xanthine by xanthine oxidase. Figure 1 shows that oxygen is consumed during the reaction. If all the hydrogen peroxide formed during the reaction is split into water and oxygen, there is a quantitative relation between consumed oxygen and metabolized hypoxanthine and xanthine, respectively. Thus, $1 \mathrm{~mol}$ oxygen is consumed $/ \mathrm{mol}$ hypoxanthine metabolized, and $0.5 \mathrm{~mol}$ oxygen is consumed $/ \mathrm{mol}$ xanthine oxidized to urate.

By measuring the decrease of $\mathrm{P}_{\mathrm{O}_{2}}$ of the solution after addition of xanthine oxidase, a quantitative measure of the oxypurine concentration is obtained. It is presupposed that all of the oxypurines are metabolized to urate. The following equation is then valid.

$$
\begin{aligned}
& \text { Hypoxanthine }+\mathrm{O}_{2}=\text { urate } \\
& \text { Xanthine }+1 / 2 \mathrm{O}_{2}=\text { urate }
\end{aligned}
$$

\section{CALCULATIONS}

Henry's law states that $\mathrm{dP}=\mathrm{KdC}$, where $\mathrm{dP}$ is the change in partial pressure of a gas in solution where the concentration of the gas is changed $\mathrm{dC}$. $\mathrm{K}$ is a constant depending upon the solution, among other things. If $\mathrm{K}$ is known, $\mathrm{dC}$ can be calculated if $\mathrm{dP}$ is measured.

It follows that

$$
\mathrm{K}=\frac{\mathrm{P} \cdot \mathrm{Mw}}{\mathrm{V} \cdot \mathrm{S}}
$$

$\mathrm{P}$ is the partial pressure of the gas in the solution. Mw is the molecular weight of the gas, $V$ is the volume of gas dissolved per liter of solution, and $\mathrm{S}$ is the specific density of the gas.

In 1 liter of plasma at $38^{\circ}$ and $760 \mathrm{~mm} \mathrm{Hg}$ of oxygen, $24 \mathrm{ml}$ oxygen are dissolved. (The volume corrected to standard pressure and temperature (14)). The specific density of oxygen (micrograms per microliter) at standard temperature and pressure is 1.429 (6). The molecular weight of oxygen is 32 . The constant $\mathrm{K}$ for oxygen dissolved in plasma is therefore

$$
\mathrm{K}=\frac{760.32 \mathrm{~mm} \mathrm{Hg}}{24,000 \cdot 1,429 \mu \mathrm{mol} / \text { liter }}=0.71=\mathrm{mm} \mathrm{Hg} / \mu \mathrm{mol} / \text { liter }
$$

